\title{
The Relationship between Mothers' Epilepsy-related Knowledge and their Healthcare Practices and Attitudes, Alexandria, Egypt
}

\author{
Hala K. Ibrahim, Assistant Professor \\ Public Health Nursing, Family Health Department, High Institute of Public Health \\ (HIPH), Alexandria University
}

\author{
Zeinab N. Shata, Lecturer \\ Mental Health, Family Health Department, High Institute of Public Health (HIPH), \\ Alexandria University
}

\begin{abstract}
Maternal knowledge about childhood epilepsy is an important aspect affecting their healthcare practices and attitudes towards their children. Objective: Assess level of mothers' knowledge about childhood epilepsy, to investigate its relation to their healthcare practices and attitudes, and to identify socio-demographic, educational and disease-related factors associated with mothers' knowledge level. Setting: The study was carried out in Smouha Health Insurance Child Mental Health Clinic affiliated to the Health Insurance Organization, Alexandria-Egypt. Subjects: The subjects of present study comprised of 308 mothers attending the clinic for follow up of their epileptic children. Tool: A predesigned questionnaire was used to assess mothers' epilepsy-related knowledge, practices and attitudes. Results: The majority of mothers (80.5\%) showed unsatisfactory knowledge. Most of them (91.9\%) agreed on observing the child all the time for safety; showed good compliance with children's medications for dose (83.4\%) and time (72.7\%). More than half (54.2\%) did not treat their children as normal ones (overprotection/rejection). The higher level of mother's knowledge was associated significantly with disagreement on observing the child all the time $(P=0.000)$, and with medication compliance $(P=0.034)$. Only grand mal seizures predicted higher level of mothers' knowledge $(B=0.961, P=0.015)$. Conclusion: Mothers' knowledge about epilepsy was considerably low. Higher knowledge level was associated with positive attitudes and practices. Recommendations: Integrating an educational component to healthcare plans of epileptic children is recommended.
\end{abstract}

Kevwords: Childhood epilepsy; Mothers' knowledge; Attitude; Practice; Egypt.

\section{Introduction}

Epilepsy is the most common chronic neurological condition that has received public health professionals' concern in the Eastern Mediterranean Region ${ }^{(1)}$. It was estimated that $40 \%$ of people who develop epilepsy annually are children under 15 years old ${ }^{(2)}$. The impact of epilepsy is most severe in children and adolescents, ${ }^{(1)}$ who show more emotional and behavioural problems, increased dependence on parents and reduced quality of life ${ }^{(3,4)}$.

Many parents of epileptic children exhibit negative beliefs, attitudes and behaviours. Parenting styles or practices include overprotection, permissiveness, rejection, low expectation from their children, treating them as sick and believing that any activity can precipitate a seizure ${ }^{(5)}$. Some parents believe epilepsy is contagious, which may end up with many children unassisted during attacks ${ }^{(6,7)}$.

The attitudes and behaviours towards epilepsy are influenced by the degree of knowledge about the condition ${ }^{(8-10)}$. Poor knowledge, cultural beliefs and stigma were considered a major concern of health professionals providing child epilepsy care, worldwide $^{(11)}$. Raising awareness about 
epilepsy was associated with improvement in attitudes towards treatment, as well as reducing stigma, social isolation, and misperceptions $^{(12-15)}$. In an Egyptian study on the quality of care of children with chronic diseases, compliance was achieved when the patient and the family received sufficient information about the disease ${ }^{(16)}$.

Epilepsy is associated with a very high treatment gap in most of the developing countries ${ }^{(1)}$. One of the implementation approaches of the WHO Programme on Reducing the Epilepsy Treatment Gap is raising awareness and educating people with epilepsy, their families, and the public about epilepsy ${ }^{(17)}$. This necessitates learning more about people's current knowledge and attitudes about epilepsy, and accordingly, developing educational messages to reduce knowledge gaps and eradicate misconceptions related to epilepsy ${ }^{(1,17)}$.

\section{Aim of the Study}

The current study aimed to assess level of mothers' knowledge about childhood epilepsy, to investigate its relation to their healthcare practices and attitudes, and to identify socio-demographic, educational and disease-related factors associated with mothers' knowledge level in Alexandria, Egypt.

\section{$\underline{\text { Research Questions: }}$}

1. What is the level of mothers' knowledge about childhood epilepsy?

2. What is the relationship between mother's epilepsy related knowledge and their healthcare practices and attitudes?

3. What are the associated factors affecting mothers' knowledge?

\section{Materials and Method}

\section{Materials}

Design: A cross-sectional study was utilized in the present study.

Setting: The study was carried out at Smouha Health Insurance Child Mental Health Clinic affiliated to the Health Insurance Organization, Alexandria, Egypt.

Subjects: The study population included mothers attending the clinic for follow up of their epileptic children. Using a caregiver's correct knowledge level of $74 \%,{ }^{(18)}$ a power of $80 \%, \alpha=0.05$, and a $5 \%$ degree of precision, the minimal required sample size was 296 mothers. Full participants were 308 mothers.

Inclusion criteria included mothers who were the main caregivers for their children, and having only one epileptic child. The response rate was almost $100 \%$.

\section{Tool:}

A structured interview using a predesigned questionnaire was developed by the researchers and was used to collect data on:

I. Socio-demographic characteristics of mothers and children, as well as educational and disease-related characteristics.

II. Mothers' knowledge about epilepsy using epilepsy-related knowledge questionnaire. This questionnaire was designed by the researchers and included 23 items measuring mothers' knowledge about epilepsy, tapping its nature, types, causes, and diagnosis (15 items). In addition, eight items were designed to assess mothers' knowledge regarding first aid measures during a seizure (3 items), and alarming signs considered an emergency and necessitate helpseeking (5 items). Each item received three responses: "Yes", 
"No", or " do not know". Scores of each item were: "2" for the right answer, "1" for the " do not know" answer, and "0" for the wrong answer. Total score of the questionnaire was calculated by summing the scores of the 23 items, and ranged from 0 to 46 . The knowledge level was categorized as: Unsatisfactory knowledge $(<50 \%)$, moderately satisfactory knowledge $(50 \%-75 \%)$, and highly satisfactory knowledge (>75\%).

III. Mothers' attitudes and practices towards epilepsy. This part consisted of questions designed by the authors based on previous literature review. The questions assessed mothers' help seeking and compliance practices and their attitudes regarding childhood epilepsy. Six questions were tapping mothers' attitudes. The mothers were asked to either "agree" or "disagree" regarding being overprotective towards the epileptic child (two questions), talking with the child about his/her illness (one question), and considering the child as a normal family member who can carry out some home tasks (one question). One question assessed mother's attitude towards her child (rejection, overprotection, same as siblings), and another one asked if the mother hides the child illness from others (not hiding, hiding from relatives only, school personnel only, friends only, or from everyone). Practice questions included seven items to assess mothers' compliance with antiepileptic drugs (AEDs), practices regarding seeking knowledge about side effects, observing the child to detect side effects, their response to side effects, and taking precautions to control triggers of seizures in the child. Each practice question received either "yes", "no", or "sometimes" response, except the question asking about the mother's response to side effects occurrence, which included three options "consulted the physician", "stopped medications", or "no response".

\section{Method}

- Permission of the head of the NorthWest Delta division of the Health Insurance Organization was obtained before starting the study.

- The tool was constructed by the researchers after review of relevant literature and was tested for content validity by juries of five experts in the field of public health from family health department and health education and behavioral sciences department, High Institute of Public Health, Alexandria University.

- The reliability of the questionnaire was tested in a pilot sample of 50 mothers, showing satisfactory internal consistency (Cronbach alpha=0.70).

- A pilot study was carried involving $10 \%$ of mothers $(n=30)$ who were not included in the study to test feasibility, clarity and applicability of the tool. Based on the obtained results, the necessary modifications were done.

- Data were collected over duration of five months from the first of August 2014 till the middle of January 2015 through interviewing the studied women individually.

\section{Ethical considerations:}

The study was approved by the Ethical Committee at the High Institute of Public Health (HIPH), Alexandria University on the basis of the Declaration of Helsinki. Research objectives were explained to the participants at the beginning of the interview and confidentiality of the 
information was assessed. Verbal consent was obtained from all participants.

\section{Statistical Analysis}

The Statistical Package for Social Sciences (SPSS, version 16; SPSS Inc, Chicago, USA) was used. Tests of significance included Chi-square $\left(X^{2}\right)$, and Fisher's exact tests. Multivariate analysis was carried out using binary logistic regression analysis to determine predictors of the higher level of mothers' knowledge. The dependent variable was mothers' knowledge level (unsatisfactory, and moderately satisfactory), while the independent variables included all variables that significantly associated with mothers' knowledge level in the univariate analysis and were viewed as a predictor of knowledge rather than an outcome of it. The effect of predictor variables was explained in terms of regression coefficient (B). A $p$ value of 0.05 or less was considered significant.

\section{Results}

\section{Results showing demographic and disease related characteristics of mothers and epileptic children:}

Mothers' ages ranged from 20-58 years, with a mean of $36.47 \pm 7.22$ years. The majority of them were married $(91.6 \%)$ and housewives $(82.5 \%)$. The highest percentages of mothers $(36.7 \%)$ were illiterates or could just barely read and write, while only $8.4 \%$ were university graduates. More than half of them $(53.2 \%)$ reported their monthly income as "adequate".

As shown in table (1), the age of epileptic children ranged from 1-17 years, with a mean of 9.32 4 4.04years. Boys outnumbered girls $(54.5 \%)$. The majority of them had two or more siblings $(72.4 \%)$, and were enrolled in the primary school (74.2\%).
Regarding disease-related characteristics, the age of onset ranged from 2 to 180 months, with a mean of $49.90 \pm 48.40$ months. As collected from medical records, petit mal epilepsy accounted for $41.9 \%$, while grand mal epilepsy represented $19.1 \%$. Presence of triggers before seizures was reported by $69.2 \%$ of mothers. The highest percentage of mothers (37\%) stated that their children's seizures decreased in frequency in the last three months, while $22.4 \%$ of them indicated increase in the frequency. Previous hospital admission was encountered in $23.7 \%$ of the children, and positive family history of epilepsy was stated in $21.4 \%$ of them (Table 1).

\section{Mothers' knowledge, attitudes and, practices:}

The majority of mothers $(80.5 \%)$ had unsatisfactory knowledge, while none of them showed highly satisfactory knowledge (Figure 1).

Table (2) depicts mothers' responses on the epilepsy-related knowledge questionnaire. Incorrect response showed the highest percentages for the majority of items. The highest incorrect responses were recorded by $85.7 \%$ of mothers who recorded incorrect response on the item stating that "An E.E.G can be used to help diagnose epilepsy", followed by $85.1 \%$ of mothers who denied that epilepsy happens due to excess electrical activity in the brain, $82.1 \%$ thought that they can give extra doses of anti-epileptic drugs (AEDs) if there is no improvement, and $76.3 \%$ viewed epilepsy as an infectious disease. Less than half $(46.1 \%)$ of them did not know that some seizures may last for seconds and cannot be noticed by others, and $43.5 \%$ said that they should restrain the child and try to stop seizures during attacks. The highest rate of correct responses was reported by $75 \%$ of mothers who said that there is no problem to give the child two doses of AEDs together on a day if the previous dose was forgotten. Mothers' knowledge on items tapping situations where seizures should be 
considered as emergency were correct for most items, and the highest percentages of them were unsure about the two items asking if a seizure should be an emergency if lasted more than five minutes $(57.5 \%)$, or if the child swallowed water during it (48.7\%).

The main sources of mothers' information were physicians and nurses $(81.5 \%)$; with the highest percentage for the physicians (69.8\%). The media was the source of information for $11.4 \%$ (8.4\% for $\mathrm{TV}$ and $3 \%$ for internet), while relatives and friends rated as the least source of information (7.1\%), (Figure 2).

Table (3) presents mothers' attitudes and practices towards epilepsy. The majority (91.9\%) agreed that they should observe their children all the time to ensure their safety. More than half of mothers believed that they should not talk with their children about their illness $(66.6 \%)$, disagreed about letting the child share with chores inside home $(54.2 \%)$, and declared that they did not treat the child as a normal child $(52.3 \%$ overprotective and $1.9 \%$ rejecting the child). Less than half of mothers (42.9\%) believed that they should prevent children from practicing hobbies or sports for safety. Only $1.9 \%$ of the mothers declared that they hid their children illness from everyone, while $75.3 \%$ of them did not hide it at all.

Regarding mothers' practices, the majority were compliant with their children's AEDs exactly as prescribed by the physician for both dose $(83.4 \%)$ and time $(72.7 \%)$, and $86 \%$ of them stated that they did not change dose or time without referring to the physician. Mothers who were seeking knowledge about side effects of AEDs represented $31.5 \%$. Among these mothers, the majority of them (80.4\%) observed their children frequently for any of the side effects, and $60.3 \%$ of them reported occurrence of side effects in their children. For those mothers whose children developed side effects, $76.6 \%$ of them responded by consulting the physician, and $12.8 \%$ stopped medications. More than half of the mothers $(55.5 \%)$ took precautions to control triggers of seizures (Table 3).

Table (4a) depicts the relationship between mothers' knowledge level and some socio-demographic, educational and disease-related factors. Although mothers' educational level was associated with higher knowledge level, yet, this association was not statistically significant $(P=0.48)$. On the other hand, the higher level of mother's knowledge was associated significantly with being the only child or having only one sibling $(P=0.017)$, better child's academic achievement $(P=0.013)$, grand mal epilepsy $(P=0.010)$, and presence of positive family history $(P=0.012)$.

Table (4b) illustrates the relationship between mothers' knowledge level and their attitudes and practices towards epilepsy. Mothers who believed that they shouldn't be overprotective to their children by observing them all the time had higher level of knowledge compared to mothers who agreed on being overprotective (52\%, vs. $16.6 \%, P=0.000)$. Positive attitudes such as considering the child as a normal child, talking with him/her about the disease, assigning some home tasks to the child, and not hiding his/her illness from others were associated with higher levels of mothers' knowledge, however, these associations were not statistically significant $(P>0.05)$. Compliance with AEDs revealed significant association with mothers' level of knowledge. Mothers who were compliant with both dose and time of medications had the highest knowledge level followed by mothers who were compliant in one aspect only (dose or time of AEDs) in comparison to mothers who were not compliant at all $(22.8 \%, 16.3 \%$ vs. $6.5 \%$, respectively, $P=0.034)$.

Table (5) displays summary results of logistic regression analysis of predictors of mothers' knowledge level. Independent variables are displayed in Table 5. Results showed that, only grand mal seizures predicted the higher level of mothers' knowledge by 2.61 times more than petit 
mal epilepsy $(\mathrm{B}=.961, P=0.015)$. The presence of positive family history of epilepsy showed marginal statistical significance as a predictor of mothers' knowledge $(\mathrm{B}=.864, P=0.052)$.

\section{Discussion}

Findings of the current study about mothers level of knowledge were similar to those of other studies in the developing countries $^{(15,19)}$. In Iran (2010), ${ }^{(19)} 91.4 \%$ of parents of epileptic children reported low or medium knowledge about epilepsy. In a Turkish study (2009), ${ }^{(15)} 42 \%$ of parents did not know what to do to help their children during a seizure, and $51.5 \%$ knew the wrong things to do during seizures. Meanwhile, $23 \%$ of parents were unsure or wrong about the fact that absence seizure alone could indicate an attack. Gaps in mothers' knowledge were evident in all areas related to epilepsy. On the contrary, our findings were not in line with the results of McEwan et al, ${ }^{(20)}$ who reported a good knowledge level regarding causes and signs of epilepsy, among carers of epilepsy patients in UK. Differences in knowledge level may be due to many factors including the setting of the study; being a developed or developing country, educational level of carers, routine provision of educational services by care providers, different methodological factors, as well as cultural and social factors.

Despite the overall unsatisfactory mothers' knowledge, their knowledge on items tapping situations where seizures should be considered as emergency were correct for most items. The discrepancy between these items and the rest of the questionnaire may be attributed to the nature of these information, where they are related mainly to emergency situations, making them a priority to the physicians rather than other ordinary information, especially in a country like Egypt where Health Insurance physicians are working with a large number of cases giving them no time to mention all needed information.
Overall, mothers' attitudes towards epilepsy as a medical condition were almost negative. These findings were inconsistent with results of other studies, ${ }^{(15,18,20)}$ which showed more positive attitudes towards epilepsy patients who were viewed as normal family and community members, and they received information about their illness from parents in $80 \%$ of cases. Less than half of mothers $(42.9 \%)$ believed that they should prevent children from practicing hobbies or sports for safety. Similar result was reported by Hirfanoglu et al, ${ }^{(15)}$ where $33.8 \%$ of parents indicated that epilepsy meant that a child could not be active in sports.

Although epilepsy has been perceived as a stigmatizing condition in both developed and developing countries, ${ }^{(1)}$ the majority of mothers in this study believed that they should not hide their children illness from others. This positive attitude could be the result of the sample selection, where these mothers were recruited from a medical care-seeking setting which means that, they were the ones who most likely did not hide their children conditions and they believed that they should seek medical advice.

While the overall mothers' knowledge and attitudes were unsatisfactory, their healthcare practices towards epilepsy were satisfactory for most situations. The majority of mothers showed good practices in relation to AEDs administration and precautions to decrease frequency of seizures. This may result because such practices are usually the main concern of the physicians who give clear instructions about them to mothers during the medical visit. On the other hand, only one third of mothers were seeking knowledge about side effects of the AEDs. This is finding may be attributed to mothers themselves, who are mainly concerned about the effect of AEDs on their children cognitive functions and scholastic achievement rather than being the physicians' concern. This explanation is supported by the finding of Lewis et $a{ }^{(21)}$ 
who stated that parents of epileptic children perceived that physicians were not responding to their concerns about the side effects and they focused only on medication management and number of seizures.

Several studies reported that better knowledge about epilepsy is associated with better attitudes and practices ${ }^{(15,21,22)}$. In the current study, poor maternal knowledge was associated significantly with their overprotective attitude, while mothers' high knowledge level was related significantly with their compliance practices. The relationship between maternal knowledge and other socio-demographic, educational, and disease-related factors were investigated. Some of these factors were considered as outcomes for the knowledge level, while others were considered as predictors of it. Mothers' satisfactory knowledge was associated with the better child's scholastic achievement. Being more knowledgeable will lead to better practices and it is expected that these children consequently will lead a better life including their scholastic performance. Hirfanoglu et al. ${ }^{(15)}$ indicated that parents' good knowledge was associated with fewer seizures, while children's poor knowledge was associated with their poor school performance.

Other factors that showed significant association with better maternal knowledge included being the only child or having only one sibling, grand mal epilepsy, and positive family history. All these factors are viewed as determinants of mothers' knowledge level. It is expected that mothers will seek information if they have only one child or a child with the least number of siblings making this child more valued by the mother. This finding was similar to that reported by Hirfanoglu et al. ${ }^{(15)}$ Also, the severe nature of grand mal epilepsy with its associated convulsions may motivate mothers to seek information more than mothers of children with petit mal epilepsy, that pass unnoticed in most cases. Likewise, having a previous experience in the family will increase mothers' knowledge and makes them more prepared when receiving their children's diagnoses or provide them with an nearby source of information inside their families.

\section{Strengths and limitations of the study}

The interview method that was used in data collection in this research allowed mothers of epileptic children to share their feelings and thoughts towards their children illness, and at the same time it was a good opportunity for the researchers to draw mothers' attention to the importance of gaining correct knowledge about epilepsy and its impact on their children's health and social life. However, the current work has some limitations. First, this research targeted mothers only, while fathers' or other informal carers' knowledge and care aspects were not investigated. Second, conducting this study in a governmental health care facility overlooked the private sector of health care and its attendants who come from different social strata.

\section{Conclusion}

Maternal knowledge about childhood epilepsy was substantially low. Higher level of knowledge was associated with good practices and attitudes, indicating the importance of mothers' awareness about the condition. These findings highlight the need to raise mothers' knowledge about their children's illness and its related healthcare aspects through health education programs provided by medical and paramedical healthcare professionals.

\section{Recommendations}

These findings highlight the need to raise mothers' knowledge about their children's illness and its related healthcare aspects through health education programs provided by medical and paramedical healthcare professionals. 
Table (1): Socio-demographic, educational and disease-related characteristics of epileptic children, Alexandria, Egypt $(\mathbf{n}=308)$

\begin{tabular}{|c|c|}
\hline Characteristics of the children & No. $(\%)$ \\
\hline Socio-demographic characteristics & \\
\hline Age (range) & $1-17$ years \\
\hline Mean $\pm S D$ & $9.32 \pm 4.04$ \\
\hline $\begin{array}{l}\text { Gender } \\
\text { Boys } \\
\text { Girls }\end{array}$ & $\begin{array}{l}168(54.5) \\
140(45.5)\end{array}$ \\
\hline $\begin{array}{l}\text { Family size } \\
<4 \text { members } \\
4-6 \text { members } \\
>6 \text { members } \\
\end{array}$ & $\begin{array}{c}39(12.7) \\
240(77.9) \\
29(9.4)\end{array}$ \\
\hline $\begin{array}{l}\text { Number of siblings } \\
\text { None or only one } \\
\geq 2\end{array}$ & $\begin{array}{c}85(27.6) \\
223(72.4)\end{array}$ \\
\hline Educational characteristics & \\
\hline $\begin{array}{l}\text { School grade }(\mathbf{n}=\mathbf{2 6 4})^{\mathbf{a}} \\
\text { Kindergarten } \\
\text { Primary } \\
\text { Preparatory } \\
\text { High } \\
\end{array}$ & $\begin{array}{c}14(5.3) \\
196(74.2) \\
41(15.5) \\
13(5.0) \\
\end{array}$ \\
\hline $\begin{array}{l}\text { Academic achievement }(\mathbf{n}=\mathbf{2 5 0})^{\mathbf{b}} \\
\text { Poor } \\
\text { Fair } \\
\text { Good } \\
\text { Excellent }\end{array}$ & $\begin{array}{l}69(27.6) \\
59(23.6) \\
70(28.0) \\
52(20.8)\end{array}$ \\
\hline $\begin{array}{l}\text { Previous school failures }(\mathbf{n}=\mathbf{2 5 0})^{\mathbf{b}} \\
\text { No } \\
\text { Yes }\end{array}$ & $\begin{array}{c}201(80.4) \\
49(19.6)\end{array}$ \\
\hline Disease-related characteristics & \\
\hline $\begin{array}{l}\text { Age when seizures first started in months } \\
\text { (range) }\end{array}$ & 2-180 months \\
\hline Mean $\pm S D$ & $49.90 \pm 48.40$ \\
\hline $\begin{array}{l}\text { Type of seizures } \\
\text { Grand mal } \\
\text { Petit mal } \\
\text { Do not know }\end{array}$ & $\begin{array}{c}59(19.1) \\
129(41.9) \\
120(39.0)\end{array}$ \\
\hline $\begin{array}{l}\text { Presence of triggers } \\
\text { No } \\
\text { Yes }\end{array}$ & $\begin{array}{l}213(69.2) \\
95(30.8)\end{array}$ \\
\hline $\begin{array}{l}\text { Frequency of seizures in the last three months } \\
\text { Increased } \\
\text { Decreased } \\
\text { Stopped } \\
\text { No change }\end{array}$ & $\begin{array}{c}69(22.4) \\
114(37.0) \\
48(15.6) \\
77(25.0)\end{array}$ \\
\hline $\begin{array}{l}\text { Previous hospital admission } \\
\text { No } \\
\text { Yes }\end{array}$ & $\begin{array}{c}235(76.3) \\
73(23.7)\end{array}$ \\
\hline $\begin{array}{l}\text { Family history of epilepsy } \\
\text { No } \\
\text { Yes }\end{array}$ & $\begin{array}{c}242(78.6) \\
66(21.4)\end{array}$ \\
\hline
\end{tabular}

${ }^{\mathrm{a}} 44$ children were not enrolled in kindergarten or school, ${ }^{\mathrm{b}}$ children enrolled in kindergarten were excluded 


\section{Mothers' knowledge level}

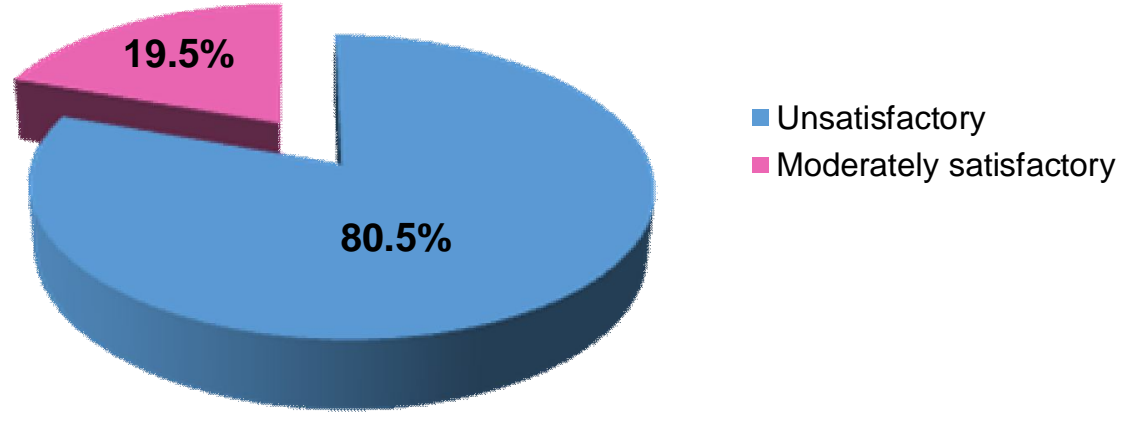

Figure (1): Level of mothers' knowledge according to their total scores on the epilepsyrelated knowledge questionnaire 
Table (2): Mothers' responses on the epilepsy-related knowledge questionnaire, Alexandria, Egypt $(n=308)$

\begin{tabular}{|c|c|c|c|}
\hline \multirow[b]{2}{*}{ Knowledge questionnaire items (answers) } & \multicolumn{3}{|c|}{ Mothers' responses $(n=308)$} \\
\hline & $\begin{array}{l}\text { Correct } \\
\text { No. }(\%)\end{array}$ & $\begin{array}{c}\text { Incorrect } \\
\text { No. }(\%)\end{array}$ & $\begin{array}{l}\text { "Do not } \\
\text { know" } \\
\text { No. }(\%)\end{array}$ \\
\hline Epilepsy is one of the infectious diseases (False) & $7(2.3)$ & $235(76.3)$ & $66(21.4)$ \\
\hline Epilepsy is a hereditary disease (False) & $116(37.6)$ & $112(36.4)$ & $80(26.0)$ \\
\hline $\begin{array}{l}\text { Epilepsy happens due to abnormal electrical } \\
\text { activity in the brain (True) }\end{array}$ & $9(2.9)$ & $262(85.1)$ & $37(12.0)$ \\
\hline Head injuries may cause epilepsy (True) & $34(11.0)$ & $184(59.8)$ & $90(29.2)$ \\
\hline $\begin{array}{l}\text { Lack of sleep and stress may trigger some } \\
\text { seizures (True) }\end{array}$ & $68(22.1)$ & $153(49.7)$ & $87(28.2)$ \\
\hline Fever may cause seizures (True) & $34(11.1)$ & $200(64.9)$ & $74(24.0)$ \\
\hline $\begin{array}{l}\text { Brain tumors are considered as one of the causes } \\
\text { of epilepsy (True) }\end{array}$ & $50(16.2)$ & $104(33.8)$ & $154(50.0)$ \\
\hline $\begin{array}{l}\text { Watching TV for long periods and flashing } \\
\text { lights may trigger seizures in some children } \\
\text { (True) }\end{array}$ & $61(19.8)$ & $158(51.3)$ & $89(28.9)$ \\
\hline $\begin{array}{l}\text { An E.E.G can be used to help diagnose epilepsy } \\
\text { (True) }\end{array}$ & $1(0.3)$ & $264(85.7)$ & $43(14.0)$ \\
\hline $\begin{array}{l}\text { All people with epilepsy lose consciousness } \\
\text { during seizures (False) }\end{array}$ & $113(36.7)$ & $96(31.2)$ & $99(32.1)$ \\
\hline $\begin{array}{l}\text { Some seizures may last for a matter of seconds } \\
\text { and cannot be noticed by others (True) }\end{array}$ & $65(21.1)$ & $142(46.1)$ & $101(32.8)$ \\
\hline $\begin{array}{l}\text { All those who start drugs for their epilepsy have } \\
\text { to take them for life (False) }\end{array}$ & $81(26.3)$ & $121(39.3)$ & $106(34.4)$ \\
\hline $\begin{array}{l}\text { If you forget to give your child AEDs for a day, } \\
\text { no problem to give the } 2 \text { doses together next day } \\
\text { (True) }\end{array}$ & $231(75.0)$ & $20(6.5)$ & $57(18.5)$ \\
\hline $\begin{array}{l}\text { The mother can give extra doses of AEDs if } \\
\text { there is no improvement (False) }\end{array}$ & $7(2.3)$ & $253(82.1)$ & 48 (15.6) \\
\hline $\begin{array}{l}\text { There is no need to continue taking AEDs if } \\
\text { your seizures stop (False) }\end{array}$ & $42(13.6)$ & $155(50.3)$ & $111(36.1)$ \\
\hline
\end{tabular}


Table (1): Continued

\begin{tabular}{|c|c|c|c|}
\hline \multirow[b]{2}{*}{ Knowledge questionnaire items (answers) } & \multicolumn{3}{|c|}{ Mothers' responses $(\mathrm{n}=308)$} \\
\hline & $\begin{array}{l}\text { Correct } \\
\text { No. }(\%)\end{array}$ & $\begin{array}{l}\text { Incorrect } \\
\text { No. }(\%)\end{array}$ & $\begin{array}{l}\text { "Do not } \\
\text { know" } \\
\text { No. }(\%)\end{array}$ \\
\hline \multicolumn{4}{|l|}{ During seizures, mothers should: } \\
\hline $\begin{array}{l}\text { Restrain the child and try to stop seizures } \\
\text { (False) }\end{array}$ & $78(25.3)$ & $134(43.5)$ & $96(31.2)$ \\
\hline Lay the child gently on one side (True) & $86(28.0)$ & $119(38.6)$ & $103(33.4)$ \\
\hline $\begin{array}{l}\text { Put a pillow or something soft under the head } \\
\text { (True) }\end{array}$ & $122(39.6)$ & $97(31.5)$ & 89 (28.9) \\
\hline \multicolumn{4}{|c|}{ Seizures are considered as emergency and the mother should call the ambulance if: } \\
\hline The seizure lasts more than five minutes (True) & $177(27.6)$ & $46(14.9)$ & $85(57.5)$ \\
\hline $\begin{array}{l}\text { The child swallowed water during the seizure } \\
\text { (True) }\end{array}$ & $82(26.6)$ & $76(24.7)$ & $150(48.7)$ \\
\hline The child has high fever or diabetes (True) & $159(51.6)$ & $45(14.6)$ & $104(32.8)$ \\
\hline $\begin{array}{l}\text { There is risk of a head or other serious injuries } \\
\text { (True) }\end{array}$ & $148(48.0)$ & $56(18.2)$ & $104(33.8)$ \\
\hline $\begin{array}{l}\text { The child is having trouble breathing after the } \\
\text { seizure (True) }\end{array}$ & $148(48.1)$ & $45(14.6)$ & $115(37.3)$ \\
\hline
\end{tabular}




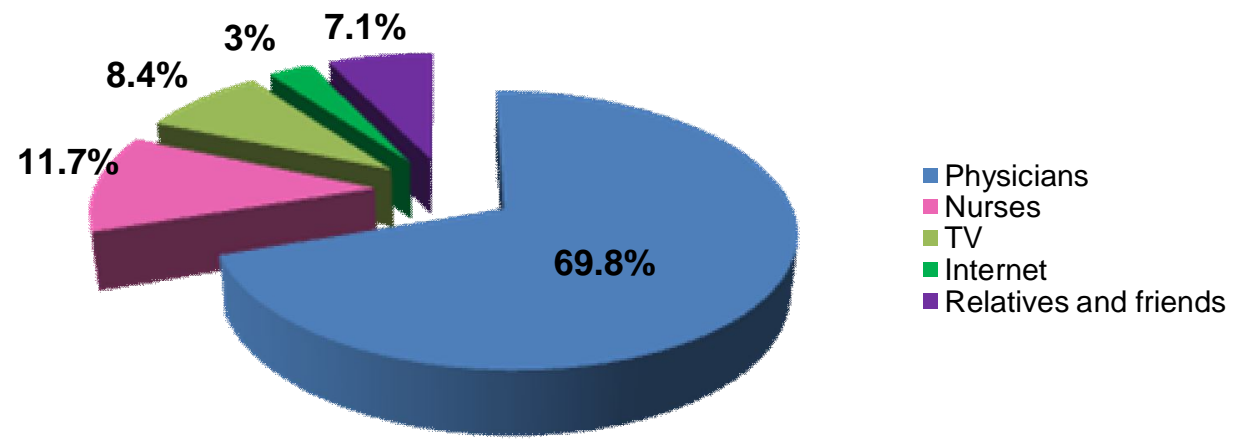

Figure (2): Sources of mothers' information about epilepsy 
Table (2): Epilepsy-related attitudes and practices of mothers, Alexandria, Egypt $(n=308)$

\begin{tabular}{|c|c|}
\hline Attitudes and practices & \multirow{2}{*}{ No. $(\%)$} \\
\hline Mothers' attitudes & \\
\hline \multicolumn{2}{|c|}{ The mother should observe the child all the time to ensure his/her safety (overprotective) } \\
\hline Disagree $^{*}$ & $25(8.1)$ \\
\hline Agree & $283(91.9)$ \\
\hline \multicolumn{2}{|c|}{ The mother should prevent the child from practicing any hobbies or sports for safety (overprotective) } \\
\hline Disagree $^{*}$ & $176(57.1)$ \\
\hline Agree & $132(42.9)$ \\
\hline \multicolumn{2}{|l|}{ The mother shouldn't talk with her child about his/her illness } \\
\hline Disagree $^{*}$ & $103(33.4)$ \\
\hline Agree & $205(66.6)$ \\
\hline \multicolumn{2}{|c|}{ The epileptic child can carry out some home tasks as a normal family member } \\
\hline Agree ${ }^{*}$ & $141(45.8)$ \\
\hline Disagree & $167(54.2)$ \\
\hline \multicolumn{2}{|l|}{ What is your attitude towards your epileptic child? } \\
\hline $\begin{array}{l}\text { I consider him/her as a normal child or the same as } \\
\text { his/her siblings }\end{array}$ & $141(45.8)$ \\
\hline I am overprotective & $161(52.3)$ \\
\hline I am rejecting the child & $6(1.9)$ \\
\hline \multicolumn{2}{|l|}{ Do you hide the illness of your child from others? } \\
\hline $\mathrm{No}{ }^{*}$ & $232(75.3)$ \\
\hline Yes, only from relatives & $31(10.1)$ \\
\hline Yes, only from school personnel (teachers, colleagues) & $28(9.1)$ \\
\hline Yes, only from his/her friends & $11(3.6)$ \\
\hline Yes, from everyone & $6(1.9)$ \\
\hline \multicolumn{2}{|c|}{\begin{tabular}{|l|l} 
Mothers' practices & \\
\end{tabular}} \\
\hline \multicolumn{2}{|c|}{ The mother is compliant in giving the DOSE of AEDs exactly as prescribed by the physician } \\
\hline Yes $^{*}$ & $257(83.4)$ \\
\hline Sometimes & $24(7.8)$ \\
\hline No & $27(8.8)$ \\
\hline \multicolumn{2}{|c|}{ The mother is compliant in giving the AEDs in TIME exactly prescribed by the physician } \\
\hline $\mathrm{Yes}^{*}$ & $224(72.7)$ \\
\hline Sometimes & 45 (14.6) \\
\hline No & $39(12.7)$ \\
\hline \multicolumn{2}{|c|}{ The mother changed the DOSE or TIME without referring to the physician } \\
\hline $\mathrm{No}^{*}$ & $265(86.0)$ \\
\hline Yes & $43(14.0)$ \\
\hline \multicolumn{2}{|c|}{ The mother was seeking knowledge about the side effects of her child's AEDs } \\
\hline Yes $^{*}$ & $97(31.5)$ \\
\hline No & $211(68.5)$ \\
\hline \multicolumn{2}{|c|}{ The mother is frequently observing her child for any side effects of AEDs $(n=97)^{\mathrm{a}}$} \\
\hline Yes $^{*}$ & $78(80.4)$ \\
\hline No & $19(19.6)$ \\
\hline \multicolumn{2}{|l|}{ The mother's response to side effects occurrence $(n=47)^{b}$} \\
\hline Consulted the physician ${ }^{*}$ & $36(76.6)$ \\
\hline Stopped medications & $6(12.8)$ \\
\hline No response & $5(10.6)$ \\
\hline \multicolumn{2}{|c|}{ The mother takes precautions to control triggers of seizures in her child } \\
\hline Yes $^{*}$ & $143(46.4)$ \\
\hline Sometimes & $28(9.1)$ \\
\hline
\end{tabular}


Table (3a): The relationship between mothers' knowledge level and some sociodemographic, educational and disease-related factors, Alexandria, Egypt (n=308)

\begin{tabular}{|c|c|c|c|}
\hline \multirow[b]{2}{*}{ Factors } & \multicolumn{2}{|c|}{ Knowledge level } & \multirow[b]{2}{*}{$X^{2}(p)$} \\
\hline & $\begin{array}{l}\text { Unsatisfactory } \\
(\mathbf{n}=\mathbf{2 4 8}) \\
\text { No. }(\%)\end{array}$ & $\begin{array}{c}\text { Satisfactory } \\
(\mathbf{n}=60) \\
\text { No. }(\%)\end{array}$ & \\
\hline $\begin{array}{l}\text { Mothers' age } \\
20- \\
33- \\
46-58\end{array}$ & $\begin{array}{c}85(84.2) \\
140(77.8) \\
23(85.2) \\
\end{array}$ & $\begin{array}{l}16(15.8) \\
40(22.2) \\
4(14.8)\end{array}$ & $2.09(0.35)$ \\
\hline $\begin{array}{l}\text { Mothers' education } \\
\text { Illiterates/just barely read and write } \\
\text { Basic education } \\
\text { Secondary education or higher }\end{array}$ & $\begin{array}{l}94(83.2) \\
63(81.8) \\
91(77.1) \\
\end{array}$ & $\begin{array}{l}19(16.8) \\
14(18.2) \\
27(22.9)\end{array}$ & $1.46(0.48)$ \\
\hline $\begin{array}{l}\text { Mothers' work } \\
\text { Housewife } \\
\text { Working }\end{array}$ & $\begin{array}{c}200(78.7) \\
48(88.9) \\
\end{array}$ & $\begin{array}{c}54(21.3) \\
6(11.1) \\
\end{array}$ & $2.92(0.08)$ \\
\hline $\begin{array}{l}\text { Child's gender } \\
\text { Boys } \\
\text { Girls } \\
\end{array}$ & $\begin{array}{l}140(83.3) \\
108(77.1) \\
\end{array}$ & $\begin{array}{l}28(16.7) \\
32(22.9) \\
\end{array}$ & $0.172(0.19)$ \\
\hline $\begin{array}{l}\text { Child's age when seizures first started } \\
\text { (years) } \\
1- \\
6- \\
11-15\end{array}$ & $\begin{array}{r}41(77.4) \\
26(78.8) \\
181(81.5) \\
\end{array}$ & $\begin{array}{l}12(22.6) \\
7(21.2) \\
41(18.5)\end{array}$ & $0.546(0.76)$ \\
\hline $\begin{array}{l}\text { Number of siblings } \\
\text { None or only one } \\
\geq 2\end{array}$ & $\begin{array}{c}61(71.8) \\
187(83.9) \\
\end{array}$ & $\begin{array}{l}24(28.2) \\
36(16.1) \\
\end{array}$ & $5.73(0.017)^{*}$ \\
\hline $\begin{array}{l}\text { Child's academic achievement }(\mathbf{n}=\mathbf{2 5 0})^{b} \\
\text { Poor } \\
\text { Fair } \\
\text { Good/Excellent }\end{array}$ & $\begin{array}{l}63(91.3) \\
50(84.7) \\
91(74.6) \\
\end{array}$ & $\begin{array}{c}6(8.7) \\
9(15.3) \\
31(25.4) \\
\end{array}$ & $8.70(0.013)^{*}$ \\
\hline $\begin{array}{l}\text { Type of seizures }(\mathbf{n}=\mathbf{1 8 8})^{\mathrm{c}} \\
\text { Grand mal } \\
\text { Petit mal }\end{array}$ & $\begin{array}{c}42(71.2) \\
112(86.8) \\
\end{array}$ & $\begin{array}{l}17(28.8) \\
17(13.2)\end{array}$ & $\begin{array}{c}6.68 \\
(0.010)\end{array}$ \\
\hline $\begin{array}{l}\text { Frequency of seizures (last three months) } \\
\text { Increased } \\
\text { Decreased } \\
\text { Stopped } \\
\text { No change } \\
\end{array}$ & $\begin{array}{l}58(84.1) \\
95(83.3) \\
33(68.8) \\
62(80.5) \\
\end{array}$ & $\begin{array}{l}11(15.9) \\
19(16.7) \\
15(31.2) \\
15(19.5) \\
\end{array}$ & $5.36(0.14)$ \\
\hline $\begin{array}{l}\text { Family history of epilepsy } \\
\text { No } \\
\text { Yes }\end{array}$ & $\begin{array}{c}202(83.5) \\
46(69.7)\end{array}$ & $\begin{array}{l}40(16.5) \\
20(30.3)\end{array}$ & $6.27(0.012)^{*}$ \\
\hline $\begin{array}{l}\text { Sources of mothers' information } \\
\text { Health care professionals } \\
\text { Media } \\
\text { Relatives \& friends } \\
\end{array}$ & $\begin{array}{l}206(82.1) \\
26(74.3) \\
16(72.7) \\
\end{array}$ & $\begin{array}{l}45(17.9) \\
9(25.7) \\
6(27.3) \\
\end{array}$ & $2.10(0.34)$ \\
\hline
\end{tabular}

$\mathrm{b}$ children enrolled in schools starting from primary level, ${ }^{\mathrm{c}}$ mothers who do not know type of epilepsy were excluded, ${ }^{*} p \leq 0.05, \quad * * 0.01, \quad * * * * 0.001$ 
Table (4b): The relationship between mothers' knowledge level and their attitudes and practices towards epilepsy, Alexandria, Egypt $(n=308)$

\begin{tabular}{|c|c|c|c|}
\hline \multirow[b]{2}{*}{ Practices and attitudes } & \multicolumn{2}{|c|}{ Knowledge level } & \multirow[b]{2}{*}{$X^{2}(p)$} \\
\hline & $\begin{array}{c}\text { Unsatisfactory } \\
\text { No. }(\%)\end{array}$ & $\begin{array}{c}\text { Satisfactory } \\
\text { No. }(\%)\end{array}$ & \\
\hline $\begin{array}{l}\text { The mother should observe the child all the } \\
\text { time to ensure safety (overprotective) } \\
\text { Disagree } \\
\text { Agree }\end{array}$ & $\begin{array}{c}12(48.0) \\
236(83.4)\end{array}$ & $\begin{array}{l}13(52.0) \\
47(16.6) \\
\end{array}$ & $\begin{array}{c}F E T \\
(0.000)^{* *}\end{array}$ \\
\hline $\begin{array}{l}\text { The mother should prevent the child from } \\
\text { practicing any hobbies or sports for safety } \\
\text { Disagree } \\
\text { Agree }\end{array}$ & $\begin{array}{l}144(81.8) \\
104(78.8)\end{array}$ & $\begin{array}{l}32(18.2) \\
28(21.2) \\
\end{array}$ & $0.442(0.50)$ \\
\hline $\begin{array}{l}\text { The mother shouldn't talk with her child } \\
\text { about his/her illness } \\
\text { Agree } \\
\text { Disagree }\end{array}$ & $\begin{array}{l}171(83.4) \\
77(74.8)\end{array}$ & $\begin{array}{l}34(16.6) \\
26(25.2)\end{array}$ & $3.27(0.07)$ \\
\hline $\begin{array}{l}\text { The epileptic child can carry out some home } \\
\text { tasks as a normal family member } \\
\text { Disagree } \\
\text { Agree }\end{array}$ & $\begin{array}{l}141(84.4) \\
107(75.9)\end{array}$ & $\begin{array}{l}26(15.6) \\
34(24.1)\end{array}$ & $3.55(0.059)$ \\
\hline $\begin{array}{l}\text { The mother's attitude towards her child } \\
\text { Exactly the same as his/her siblings } \\
\text { Overprotection/Rejection }\end{array}$ & $\begin{array}{l}108(76.6) \\
140(83.8) \\
\end{array}$ & $\begin{array}{l}33(23.4) \\
27(16.2) \\
\end{array}$ & $2.55(0.11)$ \\
\hline $\begin{array}{l}\text { Hiding the child illness from others } \\
\text { No } \\
\text { Yes }\end{array}$ & $\begin{array}{c}186(80.2) \\
62(81.6)\end{array}$ & $\begin{array}{l}46(19.8) \\
14(18.4)\end{array}$ & $0.072(0.78)$ \\
\hline $\begin{array}{l}\text { Compliance with the AEDs } \\
\text { Compliance with both dose and time } \\
\text { Compliance with either dose or time } \\
\text { Not compliant }\end{array}$ & $\begin{array}{l}169(77.2) \\
36(83.7) \\
43(93.5) \\
\end{array}$ & $\begin{array}{c}50(22.8) \\
7(16.3) \\
3(6.5) \\
\end{array}$ & $6.77(0.034)^{*}$ \\
\hline $\begin{array}{l}\text { The mother was seeking knowledge about } \\
\text { the side effects of her child's AEDs } \\
\text { No } \\
\text { Yes }\end{array}$ & $\begin{array}{c}169(80.1) \\
79(81.4)\end{array}$ & $\begin{array}{l}42(19.9) \\
18(18.6)\end{array}$ & $0.077(0.78)$ \\
\hline $\begin{array}{l}\text { Changing the dose or time of AEDs without } \\
\text { referring to the physician } \\
\text { No } \\
\text { Yes }\end{array}$ & $\begin{array}{c}209(78.9) \\
39(90.7)\end{array}$ & $\begin{array}{c}56(21.1) \\
4(9.3) \\
\end{array}$ & $3.30(0.06)$ \\
\hline $\begin{array}{l}\text { Taking precautions to control triggers of } \\
\text { seizures } \\
\text { Yes } \\
\text { No/Sometimes }\end{array}$ & $\begin{array}{l}116(81.1) \\
132(80.0) \\
\end{array}$ & $\begin{array}{l}27(18.9) \\
33(20.0) \\
\end{array}$ & $0.61(0.80)$ \\
\hline
\end{tabular}

$p \leq 0.05, \quad p \leq 0.001$ 
Mothers' Epilepsy-Related Knowledge, Healthcare Practices and Attitudes

Table (5): Summary results of logistic regression analysis of significant variables related to mothers' knowledge, Alexandria, Egypt

\begin{tabular}{||l|c|c|c|c||}
\hline Independent variables & $\mathbf{B}$ & $\begin{array}{c}\text { Standard } \\
\text { Error } \\
\text { (SE) }\end{array}$ & $\boldsymbol{P}$ - value & Exp (B) \\
\hline None or only one sibling & .708 & .450 & .116 & 2.030 \\
\hline Family history of epilepsy & .864 & .445 & .052 & 2.372 \\
\hline Seizures type (grand mal epilepsy) & .961 & .396 & .015 & $2.614^{*}$ \\
\hline Constant & -2.265 & .331 & .000 & .104 \\
\hline \hline
\end{tabular}




\section{References}

1. World Health Organization (WHO). Epilepsy in the WHO Eastern Mediterranean Region: bridging the gap. Cairo: Cairo: World Health Organization Regional Office for the Eastern Mediterranean; 2010.

2. Forsgren L. Epidemiology and prognosis of epilepsy and its treatment. In: The treatment of epilepsy. Edited by: Shorvon S, Perucca E, Fish D, Dodson E. Blackwell Publishing, Blackwell Science Oxford; 2004:21-42.

3. McEwan MJ, Espie CA, Metcalfe J, Brodie MJ, Wilson MT. Quality of life and psychosocial development in adolescents with epilepsy: a qualitative investigation using focus group methods. Seizure 2004; 13:15-31.

4. Keene DL, Manion I, Whiting S, Belanger E, Brennan R, Jacob P, et al. A survey of behavior problems in children with epilepsy. Epilepsy and Behavior 2005; 6:581-6.

5. Thompson PJ, Upton D. Quality of life in family members of persons with epilepsy. In Trimble R, Dodson WE (eds). Epilepsy and quality of life. New York: Raven Press, 1994; 2:19-31.

6. Wu KN, Lieber E, Siddarth P, Smith K, Sankar R, Caplan R. Dealing with epilepsy: Parents speak up. Epilepsy Behav 2008; 13:131-8.

7. Saengpattrachai M, Srinualta D, Lorlertratna N, Pradermduzzadeeporn E, Poonpol F. Public familiarity with, knowledge of, and predictors of negative attitudes toward epilepsy in Thailand. Epilepsy Behav 2010; 17:497-505.

8. El Sharkawy G, Newton C, Hartley S. Attitudes and practices of families and health care personnel toward children with epilepsy in Kilifi, Kenya. Epilepsy Behav 2006; 8:201-12.
9. Shafiq M, Tanwir M, Tariq A, Kasi PM, Zafar M, Saleem A, et al. Epilepsy: public knowledge and attitude in a slum area of Karachi, Pakistan. Seizure 2007; 16(4):330-7.

10. Sell Salazar F. Psychosocial aspects of childhood epilepsy. Medicina 2009; 69:3-7.

11. Atlas: epilepsy care in the world, 2005. Geneva, World Health Organization, 2005.

12. De Jong JT. A comprehensive public mental programme in Guinea-Bissau: a useful model for African, Asian, and Latin American countries. Psychological Medicine 1996; 26:97108.

13. Shorvon SD, Farmer PJ. Epilepsy in developing countries: a review of epidemiological, sociocultural and treatment aspects. Epilepsia, 1998; 29:S36-S54.

14. Scott RA, Lhatoo SD, Sander JWAS. The treatment of epilepsy in developing countries: where do we go from here? Bulletin of the World Health Organization 2001; 79(4):344-51.

15. Hirfanoglu T, Serdaroglu A, Cansu A, Soysal AS, Derle E, Gucuyener K. Do knowledge of, perception of, and attitudes toward epilepsy affect the quality of life of Turkish children with epilepsy and their parents? Epilepsy Behav. 2009; 14(1):71-7.

16. Bassili A, Zaki A, Zaher SR, El-Sawy $\mathrm{IH}$, Ahmed MH, Omar M, et al. Quality of care of children with chronic diseases in Alexandria, Egypt: the models of asthma, type I diabetes, epilepsy, and rheumatic heart disease. Egyptian-Italian Collaborative Group on Pediatric Chronic Diseases. Pediatrics 2000; 106(1):1-8. 
17. World Health Organization (WHO). WHO information kit on Epilepsy: What you can do? Geneva: World Health Organization; 2015.

18. Elliott J, Shneker B. Patient, caregiver, and health care practitioner knowledge of, beliefs about, and attitudes toward epilepsy. Epilepsy Behav. 2008; 12 (4): 547-56.

19. Behrouzian F, Neamatpour S. Parental knowledge and mental health in parents of children with epilepsy. Pak J Med Sci 2010; 26(1):191-4.

20. McEwan L, Taylor J, Casswell M, Entwistle R, Jacoby K, Gorry J, Jacoby A, Baker GA. Knowledge of and attitudes expressed toward epilepsy by carers of people with epilepsy: A UK perspective. Epilepsy Behav. 2007; 11:13-9.
21. Lewis SA, Noyes J, Mackereth S. Knowledge and information needs of young people with epilepsy and their parents: Mixed-method systematic review. BMC Pediatrics 2010; 10:1038.

22. Lim KS, Wo MC, Ahmad SA, Tan CT, Malaysian Society of Epilepsy Research Group. Only certain aspects of knowledge have impact on attitudes toward epilepsy. Neurology Asia 2013; 18(4):361-8. 